\title{
NEGATIVE INFLUENCE OF AGRICULTURAL WASTE PRODUCTS TO THE ENVIRONMENT
}

\author{
Boris Jarinovskis \\ Rezekne Higher Education Institution, Latgalian Research Institute of \\ Stable development, Latvia
}

\begin{abstract}
Research works have been made to determine the negative influence of agricultural waste products from peasant farms to the environment in eastern region of Latvia (Latgale). It is ascertained that since Latvia has got independence, great amount of peasant farms have been established which have got from 2 to 10 ha of land in property in most cases where peasants keep cattle, grow crops and vegetables for their needs. As a rule peasant has 1-2 cattles, pigs, hens, sometimes sheeps. There are also another farms with great amount of land and cattle but not so many. Technology of waste recycling is used in such farms. State control of water pollution is also conducted. Ground and underground waters are polluted in peasant farms. The main reasons of pollution are: chemical (mineral fertilizers, pesticides, oil products); bilogical (manure, liquid manure, dead bodies of animals and wastes ); domestic (glass and plastic packages (capacities), polyethylene of greenhouses, used domestic electrical devices). Mass burning of last year's grass in last years is a result of destruction of useful ground microorganisms, flora and fauna. Lack of depositories for manure, inappropriate use of manure and liquid manure causes too much nitrates in ground and pollution with helmits. The main reasons of ecosystem's pollution are: individual peasants' low level of ecological culture, incomplete legislation. There are a lot of both national and European legislative Acts that regulate toxicants' influence to the environment but all of them need to be unified. Almost all of the legislative Acts are accesible on the Internet, besides they are requiring payment, but the Internet is not available for majority of peasants. Activities for reduction of environmental pollution are offered in connection with such situation. Such activities are: perfection of legislation, establishing system of agricultural waste products' gathering, sorting and recycling, establishing depositories for manure and technologies for manure's using, creation of "waste free" technology for cattle's slaughter, meat and dairy production's processing, making the role of State services and public organisations in increasning ecological competence of population more important, apportioning extra finances for environmental protection in peasant farms.
\end{abstract}

\section{KEYWORDS}

Agricultural waste; Environment; Pollution.

\section{INTRODUCTION}

The six statistic regions in Latvia are defined by Cabinet of Ministers in 2004: Riga, region of Riga, Vidzeme, Zemgale, Latgale. Latgale is a historical-cultural region in eastern Latvia, one of the most interesting and distinctive part of republic. 
Latgalian height takes majority of Latgale's territory, the highest part of which is located to the south-east of lake Reznas. Latgale is called The region of blue lakes. Lakes occupy $6 \%$ of Latgalian height's territory. Among 15 Latvian lakes, area of which is more than $10 \mathrm{~km}^{2}$, four are located there: Reznas, Rushonu, Sivera, Ezha (see figure 1).

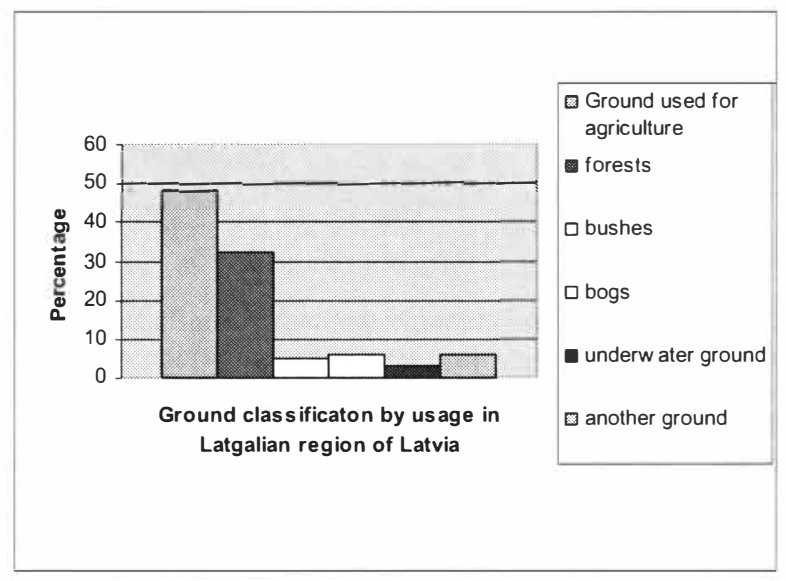

Figure ., Ground classification by usage in Latgalian region of Latvia.

Agriculturaly used lands, woods, water basins occupy considerable part of Latgale's territory . By area among other regions Latgale occupies sizeable territory of Latvia (see Table 1). By analysing the situation of the environment in Latvia, it is possible to name a number of problems, some of them are priority [1]:

- Pollution of the environment because of transfering through frontier regions;

- Water basins' overgrowning and degradation of ecosystems' waters;

- Degradation of ground's ecosystems;

- Influence of dumps to the environment;

- Increasing of wastes from imported goods;

- Transports' influence to the environment;

- Decrease of biological diversity;

- Irrational using of ground resources;

- Low quality of drinkable water.

Majority of the mentioned problems also concern western region. According to the Latvian Republic's (LR) normative Acts pollution from peasants' farms is divided into three categories: A, B, C. Strictest environment's protection demands are made for A category's pollution, lesser for C category. Only some farms are informed about pollution's categories and necessary permission.

A category permission for making polluted activiteis is necessary for farms that grow:

- more than 40,000 domestic birds;

- more than 2,000 pigs that weigh more than $30 \mathrm{~kg}$; 
- more than 750 sows.

All the other farms that grow 10 (in environment's sensetive territory -5) and more animals' unities on commercial purposes are included in C category. Animals' unity - conditioned animal that is able to produce $100 \mathrm{~kg}$ of nitrogen from cattle manure in one year after its preservation. For example one cow is equal to 0,7 of animals' unity [2, 3].

Since Latvia has got independence, great amount of peasant farms have been established whiches have got from 2 to 10 ha of land in property in most cases where peasants keep cattle, grow crops and vegetables for their needs. As a rule peasant has 1-2 cattles, pigs, hens, sometimes sheeps.

There are also another farms with great amount of land and cattle but not so many. By intensity of pollution these farms concern $\mathrm{C}$ category. Permisssion for $\mathrm{C}$ category's activities is not handed out, but before doing something or before important changes notification is handed in to the Regional environment administration.

Table 1. Characteristic of statistic regions of Latvia.

\begin{tabular}{lccc}
\hline & $\begin{array}{c}\text { Area } \\
(\% \text { of state } \\
\text { territory })\end{array}$ & $\begin{array}{c}\text { Number of inhabitants } \\
(\% \text { of total number })\end{array}$ & $\begin{array}{c}\text { Number of } \\
\text { inhabitants to } 1 \mathrm{~km}^{2}\end{array}$ \\
\hline Latvia & 100 & 100 & 35.5 \\
\hline Riga & 0.5 & 31.7 & $2,368.4$ \\
\hline Rigion of Riga & 15.7 & 16.1 & 36.4 \\
\hline Vidzeme & 23.6 & 10.6 & 15.9 \\
\hline Zemgale & 16.6 & 12.5 & 26.7 \\
\hline Latgale & 22.5 & 15.7 & 24.7 \\
\hline
\end{tabular}

\section{MATERIALS AND METHODS}

Research works have been made to find out negative influence of agricultural waste products from peasant farms to the environment in eastern region of Latvia (Latgale). Analyses of 24 peasant farms that have lands' area to 10 ha and cattle to 10 of Standard units have been made. Three large farms that have from 30 to 128 ha of land where they grow mostly cattle more than 10 Standard units (animals' unity), grow grain-crops for their farms' needs are analysed in the same way.

There are 180 ha of land and 33,5 Standard units of cattle in peasant farm, accordingly 128 ha and 23 Standard units of cattle are in 'Mezheni'" peasant farm, 67 ha of land and 67 Standard units of cattle in 'Silaraji" peasant farm. Pollution of the environment in investigated farms have been made according to the following basic points:

- Waste recycling;

- Water mine, systems of sewage;

- Availability and using of chemical substances;

- Smells. 


\section{RESULTS AND DISCUSSION}

It is ascertained that since Latvia has got independence, great amount of peasant farms have been established which have got from 2 to 10 ha of land in property in most cases where peasants keep cattle, grow crops and vegetables for their needs. As a rule peasant has 1-2 cattles, pigs, hens, sometimes sheeps.

There are also another farms with great amount of land and cattle but not so many. Technology of waste recycling is used in such farms. State control of water pollution also is conducted. Ground, ground and underground waters are polluted in peasant farms. The main reasons of pollution are: chemical (mineral fertilizers, pesticides, oil products); bilogical (manure, liquid manure, dead bodies of animals and wastes ); domestic (glass and plastic packages (capacities), polyethylene of greenhouses, used domestic electrical devices).

Last years siloing of green mass in polythene rolls is intensely used. It is the reason of polythene wastes' and exuded silo's juices appearing. The juice contains a lot of toxic substances (see Table 2). Wrong keeping and using of this juice causes environmental pollution.

Table 2. Chemical structure of silo's juice ( $\%)$.

\begin{tabular}{|cc|}
\hline Chemical components & Content of silo's juice $(\mathrm{g} / \mathrm{L})$ \\
\hline Dry substance & $30-100$ \\
Organic substances & $20-85$ \\
Dissolved carbohydrates in water & $3-4$ \\
Lastic acid & $5-30$ \\
Acetic acid & $5-15$ \\
Butyric acid & $0-15$ \\
Spirits & $3-6$ \\
Potassium & $0.3-0.5$ \\
Phosphorus & $0.4-0.6$ \\
Calcium & $0.2-3.0$ \\
$\mathrm{~N}-$ general & $0.2-3.0$ \\
$\mathrm{NH}_{3}-\mathrm{N}$ & $0.1-2.0$ \\
$\mathrm{NO}_{3}-\mathrm{N}$ & $0-0.2$ \\
\hline $\mathrm{pH}$ & $3.8-5.5$ \\
\hline
\end{tabular}

Ground and underground waters are polluted in peasant farms. The main reasons of pollution are: chemical (mineral fertilizers, pesticides, oil products); bilogical ( manure, liquid manure, dead bodies of animals and wastes); domestic (glass and plastic packages (capacities), polyethylene of greenhouses, used domestic electrical devices).

Mass burning of grass in last years is a result of destruction of useful ground microorganisms, flora and fauna. Lack of depositories for manure, wrong using of manure and liquid manure causes too much nitrates in ground and pollution with helmits. Pollution by manure, liquid manure causes ground and water ecosystems pollution (see Figure 2) The most part of 
depositories for manure had been built as "temporary" before or were used up in the course of exploitation, rational accumulation, keeping and punching of manure has become a weak point in system of accumulation of organic fertilizers. Researches have shown that economy of depositories for manure in Latvia is highly primitive. "'Temporary" depositories for manure exist close by more than $78 \%$ of dairy-farms. Possibility for organising placing of all the manure's mass inside, correct keeping of manure, mechanize works for its accumulation and loading is limited. Some variants of depositories for manure have been worked out by Planning Institution of Agricultural Building of Latvia, but they do not meet the requirements. The shortcoming of projects is that depository for manure is deep in the ground, precipitation always gather there on account of Latvian meteorological conditions and depository overfills too rapidly [3].

The main reasons of ecosystem's pollution are: individual peasants' low level of ecological culture, incomplete legislation. There are a lot of both national and European legislative Acts that regulate toxicants' influence to the environment but all of them need to be unified. Almost all of the legislative Acts are accesible on the Internet, besides its are requiring payment, but the Internet is not available for majority of peasants. Activities for reduction of environment pollution are offered in connection with such situation. Such activities are: perfection of legislation, establishing system of agricultural waste products' gathering, sorting and recycling, establishing depositories for manure and technologies for manure's using, creation of "waste free" technology for cattle's slaughter, meat and dairy production's processing, making the role of State services and public organisations in increasning ecological competence of population more important, apportioning extra finances for environment's protection in peasant farms.

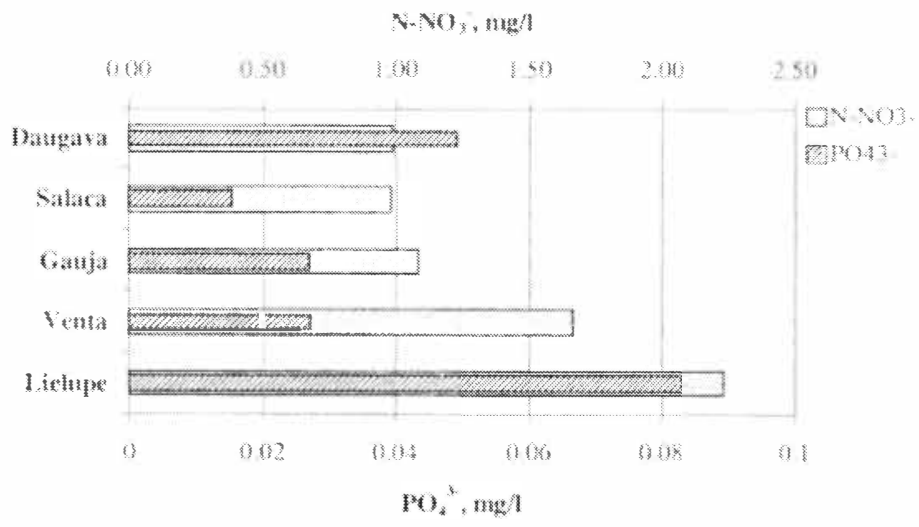

Figure 2. Concentrations of nitrates and fosfates in water of major rivers in Latvia [3].

Activities for reduction of environmental pollution are offered in connection with such situation. Such activities are: perfection of legislation, establishing system of agricultural waste products' gathering, sorting and recycling, establishing depositories for manure and technologies for manure's using, creation of "'waste free' technology for cattle's slaughter, meat and dairy production's processing, making the role of State services and public 
organisations in increasning ecological competence of population more important, apportioning extra finances for environmental protection in peasant farms.

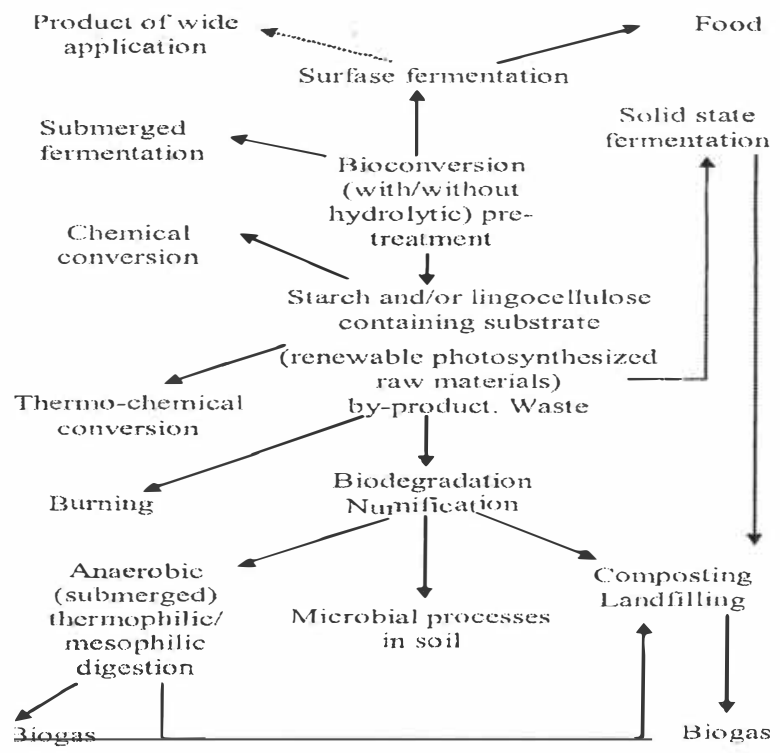

\footnotetext{
Flow diagram of the conversion of photosynthesised biomass, by-productsowaste products, including their transformation under thermal conditions
}

Figure 3. Biogas gathering technology [5].

\section{CONCLUSION}

For decreasing pollution of the environment it is necessary:

$\checkmark$ To increase ecological competence of leadres of peasants' farms and serving staff.

$\checkmark$ To assess ecosystems grounds' condition (realization of agroecological monitoring) and others ecosystems to find out the extent of pollution.

$\checkmark$ To realize agroecological monitoring using the whole complex of chemical, physical, bilogical, sanitary- hygienic indices, as well indices that define migratory, toxic properties and extent of pollution of the ground $[6,7]$.

$\checkmark$ To practice crop rotation's inculcation and normal work of land-reclamation's systems on purpose to improve fertility of the land and decrease it's erosion.

$\checkmark$ To create system of depositories for manure on peasants farms' territories and provide technologies (biogas gathering) that do not have negative influence to the environment [5].

$\checkmark$ To provide gathering, sorting, removing nad recycling of domestic wastes and utilization of dead bodies of animals.

$\checkmark$ To regulate using of mineral fertilizers, pesticides, detergents and others chemical polluters. 
To increase control for keeping of deleterious substances by State services of the environmental protection and provide information sources about extents and sources of pollution.

$\checkmark$ To unify legislative Acts (national and ES) that are connected with environmental pollution and provide them to be available in peasants farms.

\section{REFERENCES}

[1] Jarinovskis B., 2004. Aspects of stable development of biological agriculture in Latvia`s Latgalian region: problems and perspectives. In proceedings of International scientific and practical conference of stable development, May 27-28, 2004, Minsk, Republic of Belarus, pp.277-278 (in Russian).

[2] Dursts L., 1996. Practical agroecology. Riga, Agrocultural department of Republic of Latvia, pp. 52 (in Latvian).

[3] Skromanis A., 1989. Fertility of the ground and manure's using. Avots, Riga, Latvia, pp. 70-71 (in Russian).

[4] Kḷaviņš M., Rodionovs V., Kokorīte I., 2002. Chemistry of surface waters in Latvia. University of Latvia, Riga, Latvia pp. 180-185.

[5] Viesturs U., Tzonkov S., Vanags U. and others, 2006. Bioprocess engineering, Avangard Prima, Sofia, Bulgaria pp. 249-250 (in English).

[6] Jarinovskis B., 2001. Some aspects of agroecological monitoring. Scientific papers volume III. Department of environmental protection, Rezekne Higher education Institution, Rezekne, Latvia, pp. 41-45 (in Latvian).

[7] Jarinovskis B., 2006. Evalution of the level of soil pollution by dangerous agents. In proceeding of conference of Optimization of ornamental and garden plant assortiment technologies and envoronment, December 1-2, 2006, Kaunas, Lithuania, pp. 39-44. (in Russian). 